\title{
Ses dekades Ou Testament-teologie (1952-2012): Van één Spreker tot verskeie menslike sprekers
}

\begin{abstract}
Author:
Izak J.J. Spangenberg ${ }^{1}$

Affiliation:

${ }^{1}$ Department of Biblical and Ancient Studies, University of South Africa, South Africa

Correspondence to:

Sakkie Spangenberg

Email:

spangijj@unisa.ac.za

Postal address:

PO Box 392, Unisa 0003 ,

University of South Africa,

South Africa

Dates:

Received: 31 May 2012

Accepted: 11 Sept. 2012

Published: 31 Oct. 2012

How cite this article:

Spangenberg, I.J.J., 2012,

'Ses dekades Ou Testament-

teologie (1952-2012): Van

één Spreker tot verskeie

menslike sprekers',

HTS Teologiese Studies/

Theological Studies 68(1),

Art. \#1273, 9 pages.

http://dx.doi.org/10.4102/

hts.v68i1.1273
\end{abstract}

(C) 2012. The Authors.

Licensee: AOSIS

OpenJournals. This work

is licensed under the

Creative Commons

Attribution License.
Six decades of Old Testament theology (1952-2012): From hearing only One Voice to hearing many human voices. This article took a look at what has transpired in the field of Old Testament theology during the past six decades. The year 1952 saw the publication of G. Ernest Wright's book God Who Acts: Biblical Theology as Recital which is regarded as reflecting a new approach to Old Testament theology. However, the years 1970 and 1989 were also deemed to be important years in the study of the Old Testament, reflecting major changes. The six decades were thus divided into three periods (1) 1952-1970, (2) 1970-1989, and (3) 1989-2012. It was argued that the theologies which were published during the respective periods share a few common trends. This article identified and reflected on these. At the beginning of the six decades revelation through history was an important conviction and impacted on the theologies of the first period. Literary and religious studies during the seventies and nineties of the previous century had little impact on the theologies of the second and third periods. However, during the third period an Old Testament theology which set a new trend, saw the light. This theology has the title Theologies in the Old Testament and reflected a shift from hearing only One Voice in the Old Testament to hearing many human voices.

\section{Inleiding}

Die Britse historikus A.N. Wilson het in 2008 'n boek met die titel Our Times gepubliseer. Dit handel oor gebeure in Brittanje gedurende die regeringstyd van Koningin Elizabeth II. Sy het haar pa, Koning George VI, op 6 Februarie 1952 opgevolg. In die voorwoord van die boek wys hy daarop dat Koningin Elizabeth II waarskynlik Koningin Victoria se regeringstyd (63 jaar) gaan oortref en dan maak hy die volgende opmerking:

The Britain of the early 1950s is so utterly different from Britain in 2008 ... that it is bizarre to think that we have had the same Head of State as we did when rationing was still in force, and when Churchill was still Prime Minister. (Wilson 2008:1)

Die sestig jaar waaroor hierdie artikel handel, oorvleuel met die jare waaroor Wilson skryf. Soos hy, staan hierdie skrywer ook verstom voor die veranderinge gedurende die afgelope sestig jaar, maar nou nie net in soverre dit die sosio-politieke lewe in Brittanje en die res van die wêreld betref nie, maar ook in soverre dit veranderinge op die terrein van die Ou-Testamentiese wetenskap betref. Die artikel fokus slegs op een subdissipline wat bekend staan as Ou Testament-teologie en dit probeer die veranderinge oor ses dekades karteer en in perspektief plaas.

Ter motivering van die keuse vir die begindatum (1952) van hierdie oorsig, moet kennis geneem word van G. Ernest Wright se boek God Who Acts: Biblical Theology as Recital (1952) wat in dié jaar gepubliseer is. Alhoewel hierdie boek nie 'n vollengte Ou Testament-teologie is nie, bied dit ' $n$ goeie raamwerk vir 'n Ou Testament-teologie en volgens C. van Leeuwen (1986:221) het hierdie boek 'n nuwe rigting in Ou Testament-teologie ingeslaan. John Bright se boek The Kingdom of God: The Biblical Concept and Its Meaning For the Church (1953) wat 'n jaar later gepubliseer is, is ' $n$ teologie uit dieselfde dampkring en een wat in lyn lê met Wright se denke. Hierdie twee boeke vorm na regte gesamentlik die beginpunt van die historiese oorsig, want beide neem die geskiedenis van Israel as vertrekpunt en ordeningsbeginsel.

\section{Wat behels Ou Testament-teologie?}

Daar bestaan géén eenvormige definisie van Ou Testament-teologie, géén riglyne oor wat die inhoud van die dissipline is of behoort te wees, en géén omskrywing van die metode wat in die ontwerp en skryf daarvan gevolg moet word nie (Van Leeuwen 1986:211). Sommige meen dat dit ' $n$ historiese dissipline is waarin omskryf word hoe Jahwe oor die eeue hom aan die Israeliete geopenbaar het. Volgens hierdie siening beskryf Ou Testament-teologie Jahwe se voortgaande openbaring aan die Israeliete en hulle reaksie daarop. Ander meen dat dit ' $n$ historiese dissipline is waarin beskryf word hoe die Israeliete oor die eeue oor Jahwe nagedink, geskryf en hoe hulle 
hom aanbid en vereer het. Eersgenoemde benadering kan as 'n benadering 'van bo' getipeer word terwyl laasgenoemde 'n benadering 'van benede' is. Nog ander is van mening dat Ou Testament-teologie poog om die goue draad wat deur al die boeke loop, te identifiseer en dan uit te wys hoe alles in die $\mathrm{Ou}$ Testament met hierdie draad verbind kan word. In die Duitse literatuur word daar dikwels van 'die Mitte des Alten Testaments' gepraat (Reventlow 1982:138-147). Sommige geleerdes meen dat die goue draad Jahwe se verbond met Israel is - hy sal vir hulle 'n God wees en hulle moet sy volk wees (Deut 27:9-10). Ander deel die siening dat die goue draad Jahwe se reddende handelinge in Israel se geskiedenis is. Nog ander meen dat die goue draad saamhang met die historiese belydenis wat in Deuteronomium 26:5-9 te vind is. Ander is weer op hul beurt oortuig dat die belydenis dat Jahwe barmhartig, genadig en vol liefde is - 'n belydenis wat in die Wet, die Profete én die Geskrifte te vind is (Eks 34:6; Jona 4:2; Ps 103:8) - die goue draad vorm. Waaroor almal dit wel eens is, is dat $\mathrm{Ou}$ Testament-teologie 'n Christelike bedryf is - dit wil sê dit is uitsluitlik Bybelwetenskaplikes in die Christelike tradisie wat hulle met die dissipline besig hou (Vriezen 1974:157; Childs 1985:7). Na my wete het nog geen Joodse Bybelwetenskaplike sy hand gewaag aan 'n Ou Testament-teologie nie. Volgens Levenson (1993) is die rede te vind in die feit dat die Tanakh'n ander rol in Judaïsme speel as wat die Ou Testament in die Christelike godsdiens speel. Wat ook merkwaardig is, is dat geen vroulike Ou-Testamentikus nog haar hand aan 'n Ou Testament-teologie gewaag het nie alhoewel Phyllis Trible (1993:47-49) enkele gedagtes neergepen het oor wat in 'n Ou Testament-teologie te vind sou wees, sou 'n bevryde vrou haar hand daaraan waag.

Hierdie historiese oorsig wil die verskillende sienings en benaderings kortliks bespreek en uitwys dat elke teologie wat gepubliseer is, iets weerspieël van die historiese periode waarin dit tot stand gekom het. Dit is egter géén OuTestamentikus beskore om 'n objektiewe, allesomvattende en altydgeldende $\mathrm{Ou}$ Testament-teologie daar te stel nie. Die Ou Testament-teologie wat skrywer X publiseer, het net soveel bestaansreg as die teologie wat skrywer $\mathrm{Y}$ publiseer (Rendtorff 1997:19). Wat wel belangrik is, is dat elke skrywer van sy eie subjektiwiteit bewus moet bly en daarom ruimte moet laat vir ' $n$ ander perspektief en ' $n$ ander omgang met die materiaal (Brueggemann 2008:18-19). Die erkenning dat elke gepubliseerde Ou Testament-teologie bestaansreg het, beteken egter nie dat elke teologie ewe goed is nie. Sommige skrywers slaag meer as ander daarin om nuwere navorsing en insigte in hul teologieë te verwerk en sodoende lesers te prikkel sodat hulle met nuwe oë na die Ou Testament en die wêreld waarin dit tot stand gekom het, kyk. Sommige skrywers slaag meer as ander daarin om 'n brug te slaan tussen die Israelitiese wêreld en die wêreld waarin die lesers van hierdie $\mathrm{Ou}$ Testament-teologie hulle bevind. Hulle slaag meer as ander daarin om aan te toon hoedat hierdie godsdienstige literatuur steeds vir Christene van belang en relevant kan wees.

\section{Drie periodes - drie episodes}

Die ses dekades wat in hierdie artikel gedek word, word in drie periodes onderverdeel, naamlik, (1) 1952-1970, (2) 19701989 en (3) 1989-2012. Dit mag na 'n arbitrêre indeling lyk, maar daar is goeie redes vir die indeling. Soos reeds vermeld, het die boek God Who Acts (Wright 1952) 'n nuwe rigting in die ontwerp van 'n Ou Testament-teologie ingelei. Die jaar 1970 word op sy beurt deur verskeie Bybelwetenskaplikes as ' $n$ waterskeidingsjaar beskou. Een hiervan is Raymond E. Brown (1981). Volgens hom kan 'n mens die studie van die Bybel in die Katolieke tradisie gedurende die twintigste eeu in drie periodes verdeel, naamlik, (1) 1900-1940, (2) 19401970 en (3) 1970-2000. Gedurende die eerste periode is die histories-kritiese benadering grootliks verwerp, maar nadat Pous Pius XII in sy sendbrief Divino aflante Spiritu (1943) die histories-kritiese bestudering van die Bybel goedgekeur het, het Katolieke Bybelwetenskaplikes met 'n vaart weggetrek om hul Protestantse kollegas in te haal. Die tweede periode word gekenmerk deur hierdie ywer. Die derde periode verteenwoordig ' $n$ periode van pynvolle aanpassings by die resultate van die histories-kritiese ondersoek. In Brown (1981:3) se eie woorde: 'it involves the painful assimilation of the implications of biblical criticism for Catholic doctrine, theology, and practice.' Ander geleerdes wat die jaar 1970 as 'n waterskeidingsjaar in die studie van die Ou Testament beskou, is Jesper Høgenhaven (1988:23-24), Mark Allan Powell (1992:14), Arrie van der Kooij (1993:58-61) en Mark Smith (2004:8). Die fokus in die studie van die Bybel het verskuif van die wêreld ágter die teks na die die wêreld ván die teks en die wêreld vóór die teks. Literatuurwetenskaplike studies van Ou-Testamentiese tekste het algemeen geword en Ou-Testamentici het ook aandag begin gee aan die resepsie van tekste. Vóór die teks staan immers verskillende interpreterende gemeenskappe en individue elk met 'n eie agtergrond en perspektief.

Wat die jaar 1989 betref, meen TIME 1989 (2009) dat dit onmiskenbaar ' $n$ jaar is waarin die wêreld ingrypend verander het. Ná 1989 kon die wêreld nie weer dieselfde wees nie. Om maar slegs twee gebeure te noem wat in die boek beskryf word soos, (1) die val van die Berlynse muur, en (2) die ontmoeting op 05 Julie 1989 tussen P.W. Botha en Nelson Mandela wat daartoe gelei het dat F.W. de Klerk hom op 11 Februarie 1990 vrygelaat en die ANC ontban het. Wat die Ou-Testamentiese wetenskap betref, is dit so dat die studie van Israel se godsdiens sedert die laat tagtiger- en vroeë negentigerjare só 'n opbloei beleef het dat die Ou-Testamentiese wetenskap nooit weer dieselfde sal wees nie. Verskeie monografieë en tydskrifartikels wat oor Israel se godsdiens handel, het rondom 1989 begin verskyn (vgl. Boshoff 1988; Cornelius 1990; De Moor 1990; Handy 1990; Smith 1990; Lemche 1991; Albertz 1992a, 1992b). Die subdissipline Godsdiens van Israel het onder die skadu van Ou Testament-teologie uitbeweeg en die beeld wat tans van hierdie godsdiens geskets word, verskil radikaal van voriges. Waar Jahwe vroeër teenoor die gode van ander Wes-Semitiese volke gestaan het, staan hy tans (soos van hulle) aan die hoof van 'n godepanteon (Handy 1995; Smith 2004:54-57) en regeer hy soos hulle oor sy hofhouding. 
Met bostaande afbakening in gedagte, fokus die res van die artikel op die belangrikste Ou Testament-teologieë wat in die verskillende periodes gepubliseer is en probeer dan bepaalde tendense uitwys wat elke periode uiteindelik tot 'n episode in die navorsingsgeskiedenis van die Ou Testament maak.

\section{Die jare 1952-1970}

Die Ou-Testamentiese wetenskap is in die middel van die twintigste eeu grootliks deur twee skole geleerdes oorheers. Dit was die Albright-Bright-Wright-skool van die Verenigde State van Amerika (VSA) en die Alt-Noth-Von Rad-skool van Duitsland. Eersgenoemde skool het die historisiteit van die Ou-Testamentiese tradisies en verhale hoog aangeslaan, terwyl laasgenoemde skool meer krities daarteenoor gestaan het. Eersgenoemde skool het ook baie waarde aan Bybelse argeologie geheg, terwyl laasgenoemde skool meer op die ontstaan en groei van Ou-Testamentiese tradisies en tekste gefokus het (Moorey 1991:104-105). Uit beide skole het 'n geskiedenis van Israel, 'n godsdiensgeskiedenis en 'n Ou Testament-teologie voortgekom. John Bright het $A$ History of Israel ([1960] 1981) geskryf, terwyl Martin Noth vir Geschichte Israels (1966) verantwoordelik was. William Albright het Yahweh and the Gods of Canaan (1968) gepubliseer en Albrecht Alt Der Gott der Väter (1959). G. Ernest Wright en John Bright het respektiewelik God Who Acts (1952) en The Kingdom of God (1953) gepubliseer, terwyl Gerhard von Rad Theologie des Alten Testament, Band 1 (1957) en Theologie des Alten Testament, Band 2 (1960) gepubliseer het.

Wright is die eerste Ou-Testamentikus wat hom losgemaak het van die konvensionele struktuur om 'n Ou Testamentteologie te skryf. Tot op daardie stadium was Ou-Testamentici geneig om sistematiese teoloë na te volg en die OuTestamentiese materiaal onder rubrieke soos 'God', 'God en mens', 'God en die wêreld' te bespreek. Vir hom is die verloop van Israel se geskiedenis nie maar 'n toevallige verloop nie God se hand is daarin sigbaar en dit is wat 'n Ou Testamentteologie moet uitspel. Bright het met sy boek The Kingdom of God (1953) by dié siening aangesluit. Hy gebruik die tema 'die koninkryk van God' om die gebeure in sowel die Ou as die Nuwe Testament te orden. Die hele Ou Testament gee blyke van 'n verwagting van die koninkryk, maar geeneen van die Israelitiese konings slaag daarin om die koninkryk te laat realiseer nie - selfs nie eens die Makkabeërs nie (Bright 1953:185-186). Dit gebeur net met die koms van Jesus: 'In the person and work of Jesus the Kingdom of God has intruded into the world' (Bright 1953:216).

Bright se boek is grootliks 'n oorvertelling van die geskiedenis van Israel tot en met Jesus se geboorte en optrede. Hierdie manier van omgang met die materiaal stem ooreen met hoe Wright gemeen het 'n Ou Testament-teologie behoort te lyk. Die 'andersheid' van Israel se godsdiens in vergelyking met die buurvolke word ook in die boek beklemtoon en dít lê eweneens in lyn met Wright se siening van Israel se godsdiens. Vergelyk die volgende opmerking van Wright (1952):

Here, then, is an utterly different God from the gods of all natural, cultural and philosophic religion. He is no immanent power in nature nor in the natural process of being and becoming. The nature of his being and will is revealed in his historical acts. (bl. 21)
Volgens Wright en Bright se oortuiging het slegs Jahwe in die geskiedenis gehandel en Israel se geskiedenis gestuur in die rigting van Jesus se koms en die geboorte van die Christelike kerk as die nuwe Israel.

Gerhard von Rad het sy Ou Testament-teologie ook aan die hand van Israel se geskiedenis gestuktureer. Vir hom moet 'n teologie van die Ou Testament die geskiedenis van Israel se belangrikste tradisies oorvertel. Die subtitels van die twee volumes van sy teologie weerspieël dit duidelik. Die eerste volume dra die subtitel Die Theologie der geschichtlichen Überlieferungen Israels (Von Rad 1957), terwyl die tweede volume die subtitel Die Theologie der prophetischen Überlieferungen Israels dra (Von Rad 1960). Ten grondslag aan hierdie tradisies lê Jahwe se ingryping in Israel se geskiedenis. Die eerste groot ingryping hou verband met die uittog uit Egipte en die vestiging in die land. Hiervan lees ons in die Heksateug en dit is hoofsaaklik 'n uitbreiding op die belydenis wat te vind is in Deuteronomium 26:5-9. Van die tweede groot ingryping lees ons in die Deuteronomistiese en die Kronistiese geskiedwerk (Von Rad 1957:352). Hierdie twee geskiedwerke hou verband met Jahwe se belofte aan Dawid dat hy sy nageslag vir ewig oor Israel sal laat regeer (2 Sam 7:8-16).

Wanneer 'n mens die Ou Testament lees, is dit egter duidelik dat Israel se weergawe van hul geskiedenis van moderne historiese navorsing verskil daarom tref Von Rad 'n onderskeid tussen heilsgeskiedenis en geskiedenis - of soos hy dit noem 'Geschichte' en 'Historie' (1957:113). Volgens die kritiese geskiedenisnavorsing was nie al die Israeliete in Egipte nie. Hulle het ook nie almal die eksodus en die tog deur die woestyn beleef nie. Nie almal was teenwoordig by die berg Sinai nie. Maar dis nie hierdie 'kritiese minimum' wat deel van 'n Ou Testament-teologie moet vorm nie die 'kerugmatiese maksimum' voorsien die materiaal vir 'n teologie. 'n Ou Testament-teologie werk met die 'feite' soos Israel dit geglo, bely en oorgelewer het. Wat 'n mens wel in ag moet neem, is dat Israel die oorleweringe telkens geaktualiseer, gekombineer en geherinterpreteer het (Von Rad 1957:123). Dit blyk baie duidelik wanneer 'n mens die Kronistiese geskiedwerk met die Deuteronomistiese geskiedwerk vergelyk. Eersgenoemde is duidelik 'n herverwerking van die oorleweringe wat in laasgenoemde te vind is.

Wanneer 'n mens by die profete kom, is dit duidelik dat hulle met die ou heilsgeskiedenis breek en hulle hoop vestig op 'n toekomstige ingryping van Jahwe in Israel se geskiedenis. Die toekomstige ingryping kon hulle egter nie anders skilder as deur middel van die ou heilsgeskiedenis nie - daarom lees 'n mens van 'n 'nuwe verbond' (Jeremia) en 'n 'nuwe uittog' (Deutero-Jesaja).

Wat die Psalms en die wysheidsliteratuur betref, beskou Von Rad (1957:352-457) dit as Israel se 'antwoord' op Jahwe se ingrypings in hul geskiedenis. Só bly hy getrou aan sy oortuiging dat alles in die Ou Testament om Jahwe se handelinge in die geskiedenis draai - al moet hy sommige Ou-Testamentiese materiaal in dié keurslyf indruk. 
Die teologieë uit die twee skole het duidelik iets met mekaar in gemeen - dit het Jahwe se dade of ingryping in Israel se geskiedenis beklemtoon (Collins 2005b:136). Die skrywers het ook beklemtoon dat hierdie siening nie by ander ou NabyeOosterse volke te vind was nie. Daardie volke het nie klem gelê op hul god(e) se ingryping in die geskiedenis nie. Om die waarheid te sê - dié soort oortuiging was by hulle afwesig.

Die drukkersink van Von Rad se teologie was nog skaars droog toe Bertil Albrektson 'n gefladder in die hoenderhok veroorsaak. Hy het in sy boek History and the Gods (1967) aangetoon dat die idee dat Jahwe in die geskiedenis ingryp glad nie so uniek was soos geleerdes gemeen het nie. Hy skryf soos volg:

The emphasis on Yhwh's rule in history as a distinctive feature of Hebrew religion echoed, of course, an opinion which dominated Old Testament theology during the last decades. But the Mesha Stone and other extra biblical texts subsequently made me wonder whether the current view was not in need of revision. (Albrektson 1967:7)

Ou-Testamentici moes as gevolg hiervan herbesin oor dit wat hulle as uniek aan Israel se godsdiens beskou het. Dit was veral die Albright-Bright-Wright-benadering tot die $\mathrm{Ou}$ Testament wat onder skoot gekom het. Maar spoedig was Von Rad en sy oortuigings ook in die spervuur. Hans Heinrich Schmid (1966) het veral sy benadering tot die Israelitiese wysheid gekritiseer. Volgens Schmid het Israel dieselfde wêreldbeskouing as sy buurvolke gedeel. Dit blyk duidelik wanneer 'n mens die ou Nabye-Oosterse wysheidsliteratuur bestudeer. Von Rad se eensydige fokus op die historiese en profetiese tradisies van Israel het verhinder dat hy sinvol met die wysheidsliteratuur en met Israel se verankering in die ou Nabye-Oosterse kultuur, kon omgaan.

'n Saak wat besonder aandag gekry het in Ou-Testamentiese studies na die Tweede Wêreldoorlog (1939-1945) was die verhouding tussen die $\mathrm{Ou}$ en die Nuwe Testament. Dit het 'n kontensieuse saak geword vanweë die lyding van miljoene Jode gedurende die oorlog. Daar was veral twee vrae wat by teoloë gespook het: 'Was die Christelike teologie medeverantwoordelik vir die tragedie?' en 'Wat is die verhouding tussen die God van Israel en Jesus Christus?' Sommige geleerdes was oortuig dat die vervangingsteologie oftewel die 'Supercessionist theology' (die oortuiging dat die Christendom Judaïsme vervang het), wél 'n rol gespeel het (Saperstein 1989:40). So ook die oortuiging dat die Ou Testament minder belangrik was in vergelyking met die Nuwe Testament. Die geleerdes van bovermelde twee skole het in hul teologieë egter hierdie soort oortuigings teengestaan. Die Ou Testament was vir hulle net so belangrik soos die Nuwe, en die God van Israel was niemand anders as die Vader van Jesus Christus nie.

Wright, Bright en Von Rad was nie die enigste Ou-Testamentici wat gedurende hierdie periode 'n Ou Testament-teologie geskryf het nie. Paul van Imschoot (1954), Edmond Jacob (1955) en J. Barton Payne (1962) het ook teologieë gepubliseer, maar dit het nie groot impak gehad nie omdat dit óf te konserwatief was (Payne), óf met die uitgediende dogmatiese struktuur gewerk het (Van Imschoot en Jacob).

\section{Die jare 1970-1989}

In die gedeelte wat oor die afbakening van die drie periodes handel, is daarop gewys dat die jaar 1970 'n waterskeidingsjaar in die studie van die Bybel was. Bybelwetenskaplikes het begin kennis neem van navorsing in ander geesteswetenskaplike departemente. Navorsing deur literatuurwetenskaplikes, sosioloë en antropoloë het hulle veral geïnteresseer. Nuwe OuTestamentiese navorsingsmetodes het ontspring en kort voor lang het Ou-Testamentici ook narratiewe ontledings van verhale, retoriese analises van tekste en resepsiegeskiedenis van boeke begin skryf. 'n Mens sou feministiese interpretasies ook hierby kon voeg (vgl. Trible 1993:36) alhoewel Vicki Phillips (1999:390) meen dat feministies-geöriënteerde Bybelwetenskaplike navorsing eers gedurende die tagtigerjare die akademiese wêreld betree het. Hierdie nuwe metodes en benaderings tot Ou-Testamentiese tekste het nie onmiddellik 'n invloed op Ou Testament-teologie gehad nie. Om die waarheid te sê daar het nog 'n lang pad voorgelê voordat die oortuiging dat die Bybel 'n menslike dokument is, veld begin wen het. Die oortuiging dat die Bybel 'n kulturele produk uit die antieke wêreld is wat weinig verskil van ander antieke geskrifte en dat die Bybel nie die direkte woorde van God bevat nie, is steeds skepties deur sommige bejeën.

Daar was wél in hierdie periode Ou-Testamentici wat daarop gewys het dat die Israeliete dieselfde denkpatrone en wêreldbeskouing as hul buurvolke gedeel het. Onder hulle neem Hans Heinrich Schmid 'n belangrike posisie in. Hy het aangetoon dat hierdie wêreldbeskouing en denkpatroon veral in die wysheidsliteratuur aangetref word (Schmid 1966). Ingebed in die natuur en die menslike samelewing is ' $n$ bepaalde orde waarmee die mens óf in harmonie, óf in disharmonie kan leef. Harmonieuse handelinge lei tot geluk, voorspoed en sukses; disharmonieuse handelinge lei tot ongeluk, rampspoed en mislukkings. Die woord salom [vrede, voorspoed, geluk] gee uitdrukking aan wat die mens kan ervaar wat in harmonie met die orde in die natuur en die samelewing leef (Schmid 1971). Hy het in 'n artikel aangetoon dat hierdie insigte ook in 'n Ou Testament-teologie benut kan word (Schmid 1974).

Teenoor Schmid se insigte en benaderingswyse staan Brevard Childs wat met sy boek Biblical Theology in Crisis (1970) te kenne gee dat Ou Testament-teologie 'n krisis beleef. Die krisis hang volgens hom daarmee saam dat Ou-Testamentici uitverkoop is aan die histories-kritiese benadering en nie besin oor die vraag waarom die Ou Testament uit 39 boeke bestaan en op 'n bepaalde manier gestruktureer is nie. Voorts neem hulle nie die totale Bybel in ag wanneer hulle 'n Ou Testament-teologie skryf nie. Dit is belangrik om uit te wys dat die teologiese idees wat in die Ou Testament voorkom, ook in die Nuwe Testament te vind is. Hy het later ' $n \mathrm{Ou}$ Testament teologie met die titel Old Testament Theology in a Canonical Context (Childs 1985) gepubliseer waarin hy sy oortuigings illustreer. Sy standpunte en argumente het heelwat reaksies ontlok. Vrae soos die volgende is gevra: 'Watter kanon moet as riglyn vir 'n teologie dien die Hebreeuse Bybel (Tanakh), die Protestantse Bybel, die Katolieke Bybel, of die Bybel van die Ortodokse Kerke?' 
Geleerdes het daarop gewys dat die verskillende kanons verband hou met verskillende geloofsgemeenskappe. Beter gestel - dit hou verband met verskillende interpreterende gemeenskappe wat op verskillende plekke gewoon en in verskillende tye geleef het (Brooke 1997:61-68). Één kanon was nog nooit normatief vir alle gemeenskappe nie. Ander het daarop gewys dat Childs sy eie oortuigings nie altyd konsekwent toepas nie. Neem die boek Daniël as voorbeeld. In die Christelike kanon word dit by die groot profete (Jesaja, Jeremia, Esegiël) gereken, maar histories-kritiese navorsing het uitgewys dat dit 'n apokaliptiese geskrif is wat uit die tweede eeu v.C. dateer. Childs hanteer dit heel korrek as 'n apokaliptiese geskrif, maar oortree daarmee sy eie stelreël dat die kanoniese konteks 'n rol in die interpretasie behoort te speel. In die Christelike kanon staan Daniël immers by die profete (Spangenberg 2012:413-415).

Kritiese gesprekke oor die kanoniese benadering tot die studie van die Ou Testament is steeds aan die orde van die dag. 'n Aantal geleerdes het wél Childs se siening ter harte geneem en daarmee begin woeker. Onder hulle tel Erich Zenger. Volgens hom verraai die volgorde van die verskillende psalms in die Psalmboek 'n 'kanoniese rasionaal' en wanneer 'n mens die psalms en die Psalmbundel bestudeer, moet hierdie rasionaal in ag geneem word (Zenger 2003). Ian Provan (1997) het egter daarop gewys dat die Israeliete nie daagliks met geskrewe tekste geleef en dit gelees het nie. In hul samelewing het belangrike persone meer gesag gedra as tekste:

Old Testament man [sic] related to God much more through holy persons and institutions and through a sort of direct personal and oral communication with God, and little or not at all through pre-existing written and authoritative holy books. (bl. 6)

Ander teologieë wat gedurende hierdie periode verskyn het, gee duidelik blyke dat hul skrywers kennis geneem het van Albrektson (1967) se kritiese opmerkings oor Jahwe se ingrypings in Israel se geskiedenis. Hulle het die oortuiging dat Jahwe homself deur die dade in die geskiedenis geopenbaar het, links gelaat. Alhoewel elke skrywer 'n eie motief in die $\mathrm{Ou}$ Testament gevind het waaromheen hy sy $\mathrm{Ou}$ Testament-teologie gestruktureer het, is dit tog moontlik om bepaalde tendense uit te wys. Daar was steeds 'n paar Ou-Testamentici wat die navorsingsresultate van die histories-kritese ondersoek belangrik geag en dit in hul uiteensetting van 'n teologie gebruik het. Onder hulle tel tel Georg Fohrer met sy Theologische Grundstrukturen des Alten Testaments (1972), Alfons Deissler met sy Die Grundbotschaft des Alten Testament: Ein theologischer Durchblick (1972), Walther Zimmerli met sy Grundriss der alttestamentlichen Theologie (1975) en Claus Westermann met sy Theologie des Alten Testaments in Grundzügen (1978). Al vier die skrywers probeer aan die gevarieerdheid in die Ou Testament reg laat geskied. Van hulle het 'n dubbelloop-tema gebruik om hul teologie te struktureer, terwyl ander meer aandag gegee het aan verskillende literatuurkorpusse waarin verskillende gods- en lewenservarings verwoord word.

Ander Ou-Testamentici het' $n$ meer konfessionele benadering gevolg. Onder hulle tel Ronald Clements met sy Old Testament Theology: A Fresh Approach (1978), Walter Kaiser met sy Toward an Old Testament Theology (1978) en Samuel Terrien met sy The Elusive Presence: Toward a New Biblical Theology (1978). Hierdie groep se teologieë weerspieël duideliker as die vorige s'n hul verankerdheid in die Christelike tradisie. Wanneer iemand 'n Ou Testament-teologie skryf, skryf hy dit met die oog op 'n kerklike gemeenskap wat die Ou Testament steeds as Woord van God beskou en daaruit leef. Clements lê byvoorbeeld besonder klem op die verhouding tussen God en Israel. Dit is 'n wederkeringe verhouding waarin die verbond en die daarmee verbandhoudende wette en stipulasies, 'n groot rol speel (Clements 1978:79-130). Terrien lê op sy beurt klem op God se teenwoordigheid. Dit is egter 'n ontwykende teenwoordigheid. God laat hom nie in menslike begrippe vasvat nie. Sy teologie fokus nie slegs op die Ou Testament nie, maar hy stoot net soos John Bright (1953) deur na die Nuwe Testament. In sy geval gaan dit egter nie om God se koninkryk wat realiteit word nie, maar om God se teenwoordigheid in Jesus wat sowel woord (logos) as wysheid (sophia) is - teenwoordig, maar soos die wysheid, ook ontwykend (Terrien 1978:473-474).

John L. McKenzie se A Theology of the Old Testament (1974) dra elemente van 'n teologie van benede. Volgens hom gaan dit in die $\mathrm{Ou}$ Testament om Israel se ondervinding van Jahwe. Israel het Jahwe egter nie net op één terrein ervaar nie, maar op verskeie daarom bespreek McKenzie die ervaring in die kultus, die geskiedenis, die natuur, die wysheid, die politiek en sosiale instellings. Sy hantering van die Ou-Testamentiese materiaal verskil radikaal van ander geleerdes s'n. Hy bespreek ook nie die verhouding tussen die Ou en die Nuwe Testament, maar stel dit dat Israel se toekoms nie ' $n$ Jesus van Nasaret voorsien het nie.

Die kwessie van die verhouding van die Ou tot die Nuwe Testament en die gesag van die Bybel was sake wat veral gedurende hierdie periode indringend deur James Barr bespreek is. Hy het verskeie boeke oor die gesag van die Bybel, openbaring in die geskiedenis, en die verhouding tussen die $\mathrm{Ou}$ en die Nuwe Testament gepubliseer (Barr 1966, 1973, 1980, 1983) - sake wat van kardinale belang was vir die skryf van 'n Ou Testament-teologie en waarvan geen Ou-Testamentikus hom kon losmaak nie.

Geeneen van die skrywers wat gedurende hierdie periode 'n Ou Testament-teologie gepubliseer het, het egter die trillings van die verskuiwing wat besig was om onder hulle voete plaas te vind, geregistreer nie - behalwe miskien twee: Hans Heinrich Schmid (1974) en Jesper Høgenhaven (1988). Hulle het egter nie 'n vollengte teologie gepubliseer nie. Schmid het slegs maar 'n artikel en Høgenhaven 'n historiese oorsig van die periode 1950-1987 geskryf. In sy historiese oorsig beklemtoon Høgenhaven dat die Ou Testament nie die objektiewe woorde van Jahwe bevat nie, maar die subjektiewe woorde van Israelitiese skrywers. Om hierdie woorde goed te begryp, moet 'n mens die historiese konteks in ag neem, daarom is histories-kritiese navorsing belangrik. In sy eie woorde:

The historical reading, which strives to uncover the 'proper meaning' of the texts, is the only way in which these texts are, at least in principle, taken seriously for what they are ... the national literature of an ancient Near Eastern people. (Høgenhaven 1988:88) 
As ons hier met die literatuur van 'n enkele ou NabyeOosterse volk te doen het, kan dit sekerlik nie as normatief vir tyd en ewigheid geld nie? Sowel Schmid as Høgenhaven het dus ingesien dat die Ou Testament hoogstens relatiewe gesag kan hê. Dit is gesagvol vir diegene wat binne die Christelike tradisie staan en daarmee identifiseer.

\section{Die jare 1989-2012}

Daar is reeds gewys op die belangrikheid van die jaar 1989 in die studie van die Ou Testament. Verskeie publikasies oor die godsdiens van Israel het kort voor 1989 begin verskyn en die negentigerjare van die vorige eeu is gekenmerk deur indringende besinnings oor die kwessie of hierdie godsdiens van meet af aan monoteïsties was, en of Jahwe soos ander Wes-Semitiese gode ook 'n vrou gehad het (Hadley 1994; Dijkstra 1995; Wyatt 1999; Collins 2005c). Daar was ook op ander terreine van die vak woelinge. 'n Stryd rondom toegang tot die Dooie Seerolle het ontstaan. Tot op daardie stadium het slegs ' $n$ handjievol uitverkore akademici toegang tot al die rolle gehad. In November 1991 het die 'Biblical Archaeological Society of Washington' 'n volledige stel foto's van die rolle sonder die medewete en toestemming van die kurators gepubliseer, en in 1992 het Emmanuel Tov 'n microfiche-uitgawe saam met die Nederlandse uitgewer E.J. Brill, die lig laat sien. Dit was twee heilsame gebeurtenisse, want nou kon enigeen wat in die rolle belanggestel het, dit lees en daaroor navorsing doen (Vermes 1998:188-209). Die studie van die Dooie Seerolle het navorsers daartoe gebring om nuut na Israel se godsdiens te kyk. Die terme 'laat Judaïsme' of 'laat Jodedom' is verruil vir 'n korrekter benaming, naamlik 'Vroeë Judaïsme' of 'Judaïsme van die Tweede Tempel-tydperk' (Boccaccini 2002:9). Nuwe teorieë oor die oorsprong van Israel is ook voorgedra en gedebateer (Lemche 1985; Davies 1992), terwyl heelwat Ou-Testamentici literatuurwetenskaplike studies gepubliseer het (Powell 1992). Van hierdie navorsing het bygedra tot verdere gesprekke oor die gesag van die Ou Testament en die Bybel. Die resultaat van hierdie gesprekke en navorsing vat Don Cupitt (2001:1) soos volg saam: 'We no longer hear One Voice in the Bible: we hear only a crowd of different human voices.'

Nie alle Ou-Testamentici het die paradigmaskuif wat teen die einde van die negentiende in die Bybelwetenskappe voorgekom het (Noll 1991:45) - en waarop die woorde van Cupitt hierbo sinspeel - hulle eie gemaak nie. Walter Brueggemann is so'n persoon. Vir hom is die Verligting (waar die wortels van die paradigmaverandering geleë is) van die bose (Brueggemann 1997:12-15). 'n Postmoderne benadering tot die Ou Testament slaag volgens hom meer daarin om die boodskap daarvan tot sy reg te laat kom. Vir hom is Israel se getuienis soos dit in die Ou Testament tot uitdrukking kom, bo verdenking. Om daardie getuienis aan historiese kritiek (of enige ander kritiek) te onderwerp, maak dit kragteloos. Wanneer Israel getuig dat Jahwe sus of só gehandel het, is dit waar en bly dit relevant vir gelowiges van watter eeu ook al. In sy teologie gebruik hy die metafoor van 'n geregshof en rangskik Israel se getuienis 'in die hof' onder vier hoofde, naamlik, (1) Israel se kerngetuienis, (2) Israel se opponerende getuienis, (3) Israel se onbegeleide getuienis, en (4) Israel se beliggaamde getuienis. James Barr (1999:544) wys tereg daarop dat die metafoor van 'n geregshof nie goed werk nie al is dit uiters kreatief. In 'n geregshof word getuies immers aan indringende vrae onderwerp om by die waarheid uit te kom - presies wat historiese-kritiese ondersoek met die Ou Testament doen. Voorts pas die laaste twee kategorieë nie mooi in by die metafoor van 'n geregshof nie. Dis duidelik dat Brueggemann die Ou-Testamentiese materiaal in 'n keurslyf indruk.

John Goldingay se teologie van die $\mathrm{Ou}$ Testament wat drie dik volumes beslaan $(2003,2006,2009)$, herinner aan Brueggemann (1997) s'n. Ook hy het nie veel ooghare vir historiese ondersoek van die Ou Testament nie. Volgens hom behoort 'n Ou Testament-teologie vertelling ('narrative') as vertekpunt te neem: 'The fact that the Old Testament opens with narrative and is dominated by narrative makes narrative form the appropriate starting point for Old Testament theology' (Goldingay 2003:32). In die eerste volume wat die titel Israel's Gospel dra (Goldingay 2003) bespreek hy Israel se 'makronarratief' onder die volgende rubrieke:

- God begin

- God begin oor

- God beloof

- God verlos

- God verseël

- God gee

- God akkommodeer

- God worstel

- God bewaar.

Hierby voeg hy 'n verdere rubriek wat die Nuwe-Testamentiese materiaal dek: God stuur. Hierdie volume herinner aan Bright se The Kingdom of God (1953) omdat dit ook uitloop op vertelling oor Jesus se koms. So word sy teologie uiteindelik 'n Bybelse teologie en nie slegs 'n Ou Testament-teologie nie. (Goldingay verkies om na die Ou Testament as die 'Eerste Testament' te verwys.)

Die tweede volume wat die titel Israel's faith dra (Goldingay 2006), handel oor die verhouding tussen Jahwe en Israel, Jahwe en die mensdom, Jahwe en die wêreld, en Jahwe en die nasies.

Hierdie volume herinner op sy beurt aan Vriezen se teologie (1974). Hy het die Ou-Testamentiese materiaal ook aan die hand van die verhouding tussen God en Israel gestruktureer, maar terwyl Vriezen hom met die resultate van die historieskritiese ondersoek besig gehou het, systap Goldingay dit. $\mathrm{Na}$ my mening is hierdie volume eintlik ' $\mathrm{n}$ bespreking van Israel se godsdiens en dit staan duidelik teenoor die kritiese rekonstruksies van Israel se godsdiens. Vir hom loop Israel se geloof sonder enige hinkstappie direk oor in die vroeë Christendom.

Die derde volume wat die titel Israel's Life dra (Goldingay 2009), is grootliks 'n soort etiek van die Ou Testament. Die volume val in drie dele uiteen, naamlik, (1) Om met God te leef, (2) om met ander te leef, en (3) om met jouself te leef. 
Vreemd genoeg - daar is geen afdeling oor 'om met die skepping te leef' nie, en dit terwyl dié saak tans almal se aandag verdien. Na my mening het ons hier na regte met drie afsonderlike werke te doen. Die eerste volume is 'n teologie, die tweede 'n godsdiens van Israel, en die derde 'n etiek van die $\mathrm{Ou}$ Testament, maar Goldingay bied al drie aan as 'n volledige en omvattende teologie van die Ou Testament.

Teenoor Walter Brueggemann en John Goldingay van die VSA staan Horst Dietrich Preuss en Otto Kaiser van Duitsland. Terwyl eersgenoemdes geen ooghare vir die resultate van die histories-kritiese ondersoek van die $\mathrm{Ou}$ Testament het nie, werk laasgenoemdes daarmee. Elkeen, weliswaar, op sy eie manier. Volgens Preuss (1991:31) is Jahwe se verkiesing van Israel die sentrale tema van die Ou Testament en hy gebruik dit om sy teologie mee te struktureer. Hy wys daarop dat verkiesing ook met pligte gepaard gaan, daarom dra die eerste volume die subtitel: JHWHs erwählendes und verpflichtendes Handeln (Preuss 1991). Jahwe se verkiesing hou verband met Israel se redding uit Egipte en die verbond wat Jahwe daarna by Sinai met hulle gesluit het. Verkiesing, redding, verbond en verbondsverpligtinge loop hand aan hand. Die tweede volume van sy teologie dra die subtitel Israels Weg mit JHWH (Preuss 1992) en hierin bespreek hy die aartsvaderverhale, die koningskap en messiaanse verwagting, die tempel en die Sionsteologie, die priesters, leviete en profete, Israel se antropologie, etos, en toekomsverwagting asook hul lewe met ander volke. Dit gaan om hoe Israel uitdrukking gegee het aan Jahwe se verkiesing in die verloop van hul geskiedenis.

Otto Kaiser se Ou Testament-teologie is 'n omvattende stuk werk wat soos Glodingay s'n uit drie volumes bestaan. In die eerste volume lê hy die basis vir sy teologie neer. Volgens sy oortuiging is die Tora die sentrale tema (of goue draad) van die Ou Testament (Kaiser 1993:329-353). In die tweede volume van sy teologie argumenteer hy dat net Deuteronomium 4-30 oorspronklik as Tora gereken is, maar dit later uitgebrei is om die totale Pentateug in te sluit (Kaiser 1998:18). Die Tora hou direk verband met Jahwe se reddingsdaad toe hy Israel van die onderdrukking in Egipte gered het. Die inleiding tot die Tien Gebooie maak dit duidelik (Eks 20:1-2). In die vormgewing aan sy oortuigings huiwer hy nie om van die navorsingsresultate van die histories-kritiese ondersoek gebruik te maak nie. Die opskrifte van sommige hoofstukke in die eerste volume weerspieël dit duidelik. So is daar 'n hoofstuk met die titel: 'God, volk en land in die postpriesterlike geskiedswerk (JEP)' (Kaiser 1993:157), en een met die titel 'God, koning, volk en land in die Deuteronomistiese en Kronistiese geskiedswerk' (Kaiser 1993:186). Die tweede volume fokus byna uitsluitlik op Jahwe as die god van Israel. Hierin bespreek hy die herkoms van Jahwe, sy wese, sy naam, sy teenwoordigheid in die tempel en op aarde, sy heiligheid, sy nabyheid maar ook gereserveerdheid. Die drie slothoofstukke handel oor Jahwe as skepper van die wêreld en die mensdom, die mens as beelddraer, en die wêreld as skepping van God - hoofsaaklik gegrond op Genesis 1:12:4a en 2:4b-2:24 (Kaiser 1998:210-318). In die derde volume word die verbond en wat dit alles inhou, ter sprake gebring (Kaiser 2003). Reg, geregtigheid, sonde en dood, oordeel, skuld, lyding en twyfel is maar enkele van die vele sake wat bespreek word.
Alhoewel 'n mens nie van 'n Brueggemann-Goldingay-skool en 'n Kaiser-Preuss-skool kan praat nie, het ons hier met 'n vergelykbare teenoorstelling as in die jare 1952-1970 te doen. Teenoor die Duitse Ou-Testamentici wat histories-kritiese navorsing belangrik ag, staan die Ou-Testamentici uit die VSA wat geen ooghare vir histories-kritiese navorsing het nie. Preuss en Kaiser se teologieë is klassieke Ou-Testament teologieë in die Duitse tradisie van Gerhard von Rad, Georg Fohrer en Walther Zimmerli.

Maar gedurende hierdie jare het 'n ander Duitse OuTestamentikus met ' $n$ teologie vorendag gekom wat radikaal anders was en 'n ander koers ingeslaan het. Dit was Erhard Gerstenberger met sy boek Theologies in the Old Testament (2002). Dit het oorspronklik in 2001 in Duits onder die titel Theologien im Alten Testament: Pluralität und Synkretismus alttestamentlichen Gottesglauben verskyn. Die Engelse vertaling het toevallig presies vyftig jaar na Wright se God Who Acts (1952) verskyn en daardeur die kontras met vorige teologieë nog verder beklemtoon. Gerstenberger werk nie met 'n sentrale tema nie en fokus nie uitsluitlik op die literatuur van die $\mathrm{Ou}$ Testament nie. Hy fokus hoofsaaklik op die groepe in Israel se samelewing soos onlangse studies dit beskryf, en bespreek dan hierdie groepe se verstaan van Jahwe en hul godsdiensbeoefening. Sy teologie stop egter nie met 'n beskrywing van hoe die verskillende groepe Jahwe beleef en vereer het nie, maar hy worstel ook met die krisisse van ons dag en daarom skryf hy in die slotparagraaf van die boek:

The question of God is a problem for humankind. Like all religious action and contemplation it is a question of being or not-being. If we want to preserve civilization on this planet, we shall have to change the way we think about God. (Gerstenberger 2002:321)

\section{Samevatting en toekomsblik}

Izak Spangenberg (1994) het gemeen dat die veranderinge op die terrein van die Ou-Testamentiese wetenskap rondom die sewentigerjare daartoe kan lei dat Ou Testament-teologie van die toneel kan verdwyn. Sy voorspelling is gedeeltelik bewaarheid. Jonger Ou-Testamentici se aandag het rondom 1989 verskuif na die studie van Israel se godsdiens en hulle het die skryf van Ou Testament-teologieë aan die ouer geslag oorgelaat. Dit was hoofsaaklik ouer Duitse Ou-Testamentici en 'evangeliese' Ou-Testamentici in die VSA wat hulle met die skryf van 'n Ou Testament-teologie besig gehou het. Die Duitse modelle het deur die bank ' $n$ affiniteit vir die resultate van die histories-kritiese ondersoek van die Ou Testament getoon, terwyl die Amerikaanse modelle byna deur die bank geen affiniteit daarvoor getoon het nie. Die teologieë wat in die VSA gepubliseer is, mag die indruk wek dat kritiese studie van die Ou Testament dáár aan die taan is. Die teendeel is egter waar. Daar is ' $n$ handvol jonger Ou-Testamentici wat ywerig deelneem aan die navorsing oor Israel se godsdiens. Neem as voorbeeld Mark Smith (2004). Die moontlikheid bestaan wel dat konserwatiewe Ou-Testamentici in die VSA steeds sal voortgaan met die skryf van teologieë op die patroon van Walter Brueggemann en John Goldingay. Dit 
wil sê, hulle sal teologieë voortbring wat nie worstel met die probleme rondom die gesag van die Bybel, die kompleksiteit van Israel se godsdiensgeskiedenis, die uitgediendheid van kerklike leerstellings, en die politieke, ekonomiese en ekologiese krisisse wat ons tans beleef nie. Maar dalk verras die toekoms ons en tree daar in die VSA Ou-Testamentici na vore wat soos Erhard Gerstenberger erns maak met die stand van navorsing op alle terreine van die Ou-Testamentiese wetenskap en wat daarin kan slaag om vanuit die $\mathrm{Ou}$ Testament met insigte na vore te kom wat ons kan help om 'n liefde vir die aarde en vir die lewe duskant die graf aan te leer. Dalk tree daar in die toekoms selfs in Suid-Afrika Ou-Testamentici na vore wat die paradigmaveranderings wat die Ou-Testamentiese wetenskap al ondergaan het, hul eie maak en erken dat ons in die Ou Testament slegs maar met menslike insigte en perspektiewe te doen kry.

\section{Erkenning}

Ek dra die artikel graag op aan Piet Venter wat deur die jare 'n lojale kollega en 'n ywerige navorser was. Hy het met sy navorsing oor die apokaliptiek, apokaliptiese literatuur en die boek Henog, die Ou-Testamentiese wetenskap in SuidAfrika verryk.

\section{Mededingende belange}

Die outeur verklaar dat hy geen finansiële of persoonlike verbintenis het met enige party wat hom nadelig kon beïnvloed in die skryf van hierdie artikel.

\section{Literatuurverwysings}

Albertz, R., 1992a, Religionsgeschichte Israels in alttestamentlicher Zeit, Teil 1: Von den Anfängen bis zum Ende der Königszeit, Vandenhoeck \& Ruprecht, Göttingen.

Albertz, R., 1992b, Religionsgeschichte Israels in alttestamentlicher Zeit, Teil 2: Vom Exil bis zu den Makkabäern, Vandenhoeck \& Ruprecht, Göttingen

Albrektson, B., 1967, History and the Gods: An essay in the idea of historical events as divine manifestations in the Ancient Near East and in Israel, Gleerup, Lund.

Albright, W.F., 1968, Yahweh and the Gods of Canaan: A Historical Analysis of Two Contrasting Faiths, Athlone, London.

Alt, A., 1959, 'Der Gott der Väter', in A. Alt (Hrsg.), Kleine Schriften zur Geschichte des Volkes Israel (Band I), bl. 1-78, C.H. Beck, München.

Barr, J., 1966, Old and New in Interpretation: A Study of the Two Testaments, SCM, London.

Barr, J., 1973, The Bible in the Modern World, SCM, London.

Barr, J., 1980, The scope and authority of the Bible, SCM, London.

Barr, J., 1983, Holy Scripture: Canon, Authority, Criticism, Clarendon, Oxford.

Barr, J., 1999, The Concept of Biblical Theology: An Old Testament Perspective, SCM, London.

Boccaccini, G., 2002, Roots of Rabbinic Judaism: An Intellectual History, from Ezekiel to Daniel, Eerdmans, Grand Rapids.

Boshoff, W.S., 1988, 'Die monoteïsme: Vroeë rigtinggewer of laat aankomeling in die godsdiensgeskiedenis van Israel?', Theologia Evangelica (South Africa) 11, 2-14.

Bright, J., 1953, The Kingdom of God: The Biblical Concept and Its Meaning For the Church, Abingdon, Nashville.

Bright, J., [1960] 1981, A History of Israel, 3rd edn., SCM, London.

Brooke, G.J., 1997, 'The Qumran Scrolls and Old Testament Theology', in H.T.C. Sun \& K.L. Eades (eds.), Problems in Biblical Theology: Essays in Honor of Rolf Knierim, pp. 59-75, Eerdmans, Grand Rapids.

Brown, R.E., 1981, “'And the Lord Said?" Biblical reflections on Scripture as the Word of God', Theological Studies 42, 3-19.

Brueggemann, W., 1997, Theology of the Old Testament: Testimony, Dispute, Advocacy, Fortress, Minneapolis.

Brueggemann, W., 2008, Old Testament Theology: An Introduction, Abingdon, Nashville. Childs, B.S., 1970, Biblical Theology in Crisis, Fortress, Philadelphia.
Childs, B.S., 1985, Old Testament Theology in a Canonical Context, SCM, London.

Clements, R.E., 1978, Old Testament Theology: A Fresh Approach, Marshall, Morgan \& Scott, London.

Collins, J.J., 2005a, The Bible after Babel: Historical Criticism in a Postmodern Age, Eerdmans, Grand Rapids.

Collins, J.J., 2005b, 'Is a Postmodern Biblical Theology Possible?', in J.J. Collins (ed.), The Bible after Babel: Historical Criticism in a Postmodern Age, pp. 131-169, Eerdmans, Grand Rapids.

Collins, J.J., 2005c, 'Israelite Religion: The Return of the Goddess', in J.J. Collins (ed.), The Bible after Babel: Historical Criticism in a Postmodern Age, pp. 99-129, Eerdmans, Grand Rapids.

Cornelius, I., 1990, 'The Sun Epiphany in Job 38:12-15 and the Iconography of the Gods in the Ancient Near East - the Palestinain Connection', Journal of Northwest Semitic Languages 16, 25-43.

Cupitt, D., 2001, Reforming Christianity, Polebridge, Santa Rosa.

Davies, P.R., 1992, In Search of 'Ancient Israel', Sheffield Academic Press, Sheffield.

Deissler, A., 1972, Die Grundbotschaft des Alten Testaments: Ein theologischer Durchblick, Herder, Freiburg

De Moor, J.C., 1990, The Rise of Yahwism: The Roots of Israelite Monotheism, Peeters, Louvain.

Dijkstra, M., 1995, 'El, YHWH and their Asherah: On Continuity and Discontinuity in Canaanite and Ancient Israelite Religion', in M. Dietrich \& O. Loretz (Hrsg.), Ugarit - Ein ostmediterranes Kulturzentrum im Alten Orient: Ergebnisse und Perspektiven der Forschung, pp. 43-73, Ugarit-Verlag, Münster.

Edelman, D.V., 1995a, 'Introduction', in D.V. Edelman (ed.), The Triumph of Elohim From Yahwisms to Judaisms, pp. 15-25, Kok/Pharos, Kampen.

Edelman, D.V. (ed.), 1995b, The Triumph of Elohim: From Yahwisms to Judaisms, Kok/ Pharos, Kampen.

Fohrer, G., 1972, Theologische Grundstrukturen des Alten Testaments, De Gruyter, Berlin.

Gerstenberger, E.S., 2002, Theologies in the Old Testament, T \& T Clark/Continuum, London.

Goldingay, J., 2003, Old Testament Theology (Volume 1): Israel's Gospel, Inter-Varsity, Downers Grove.

Goldingay, J., 2006, Old Testament Theology (volume 2): Israel's Faith, Inter-Varsity, Downers Grove.

Goldingay, J., 2009, Old Testament Theology (volume 3): Israel's Life, Inter-Varsity, Downers Grove.

Hadley, J.M., 1994, 'Yahweh and "His Asherah": Archaeological and Textual Evidence for the Cult of the Goddess', in W. Dietrich \& M.A. Klopfenstein (Hrsg.), Ein Gott allein $J H W H$-Verehrung und biblischer Monotheismus im Kontext der israelitischen und altorientalischen Religionsgeschichte, bl. 235-268, Universitätsverlag, Freiburg.

Handy, L., 1990, 'Dissenting Deities or Disobedient Angels: Divine Hierarchies in Ugarit and the Bible', Biblical Research 35, 18-35.

Handy, L., 1995, 'The Appearance of Pantheon in Judah', in D.V. Edelman (ed.), The Triumph of Elohim: From Yahwisms to Judaisms, pp. 27-43, Kok/Pharos, Kampen.

Høgenhaven, J., 1988, Problems and Prospects of Old Testament Theology, Journal for the Study of the Old Testament Press, Sheffield.

Jacob, E., 1955, Théologie de l'Ancient Testament, Delachaux et Niestlé, Neuchâtel.

Kaiser, O., 1993, Der Gott des Alten Testaments: Theologie des Alten Testaments, Teil 1: Grundlegung, Vandenhoeck \& Ruprecht, Göttingen.

Kaiser, O., 1998, Der Gott des Alten Testaments: Theologie des Alten Testaments, Teil 2: Jahwe, der Gott Israels, Schöpfer der Welt und des Menschen, Vandenhoeck \& Ruprecht, Göttingen.

Kaiser, O., 2003, Der Gott des Alten Testaments. Theologie des Alten Testaments, Teil 3: Jahwes Gerechtigkeit, Vandenhoeck \& Ruprecht, Göttingen.

Kaiser, W.C., 1978, Toward an Old Testament Theology, Eerdmans, Grand Rapids.

Lemche, N.P., 1985, Early Israel: Anthropological and Historical Studies on the Israelite Society before the Monarchy, Brill, Leiden.

Lemche, N.P., 1991, 'The development of the Israelite religion in light of recent studies of the early history of Israel', in J.A. Emerton (ed.), Congress Volume Leuven 1989, pp. 97-115, Brill, Leiden.

Levenson, J.D., 1993, 'Why Jews are not interested in biblical theology', in J.D. Levenson (ed.), The Hebrew Bible, the Old Testament and historical criticism, pp. 33-61, Westminster/John Knox, Louisville.

McKenzie, J.L., 1974, A Theology of the Old Testament, Doubleday, New York.

Moorey, R., 1991, A Century of Biblical Archaeology, Lutterworth, Cambridge.

Noll, M.A., 1991, Between Faith and Criticism: Evangelicals, Scholarship, and the Bible, Apollos, Leicester.

Noth, M, 1966, Geschichte Israels, Vandenhoeck \& Ruprecht, Göttingen.

Payne, J.B., 1962, The Theology of the Older Testament, Zondervan, Grand Rapids.

Phillips, V.C., 1999, 'Feminist interpretation', in J.H. Hayes (ed.), Dictionary of Biblical Interpretation, pp. 388-398, Abingdon, Nashville.

Powell, M.A., 1992, The Bible and Modern Literary Criticism: A Critical Assessment and an Annoted Bibliography, Greenwood, London. 
Preuss, H.D., 1991, Theologie des Alten Testaments, Band 1: JHWH's erwählendes und verpflichtendes Handeln, Kohlhammer, Stuttgart.

Preuss, H.D., 1992, Theologie des Alten Testaments, Band 2: Israel's Weg mit JHWH, Kohlhammer, Stuttgart.

Provan, I.W., 1997, 'Canons to the left of him: Brevard Childs, his critics, and the future of Old Testament theology', Scottish Journal of Theology 50, 1-38. http://dx.doi. org/10.1017/S0036930600036115

Rendtorff, R., 1997, 'Approaches to Old Testament Theology', in H.T.C. Sun \& K.L. Eades (eds.), Problems in Biblical Theology: Essays in Honor of Rolf Knierim, pp. 13-26, Eerdmans, Grand Rapids.

Reventlow, H.G., 1982, Hauptprobleme der alttestamentlichen Theologie im 20. Jahrhundert, Wissenschaftliche Buchgesellschaft, Darmstadt.

Saperstein, M., 1989, Moments of Crisis in Jewish-Christian Relations, SCM, London.

Schmid, H.H., 1966, Wesen und Geschichte der Weisheit, Töpelmann, Berlin.

Schmid, H.H., 1971, Salôm 'Frieden' im Alten Orient und im Alten Testament, Katholisches Bibelwerk, Stuttgart.

Schmid, H.H., 1974, 'Altorientalische Welt in der alttestamentlichen Theologie', in H.H. Schmid (Hrsg.), Altorientalische Welt in der alttestamentlichen Theologie, bl. 145-164, Theologischer Verlag, Zürich.

Smith, M.S., 1990, The Early History of God: Yahweh and the Other Deities in Ancient Israel, Harper \& Row, San Francisco.

Smith, M.S., 2004, The Memoirs of God: History, Memory and the Experience of the Divine in Ancient Israel, Fortress, Minneapolis.

Spangenberg, I.J.J., 1994, 'Paradigm change and Old Testament theology: Death-blow to a non-existent beast?' Old Testament Essays 7, 435-452.

Spangenberg, I.J.J., 2012, 'The Book of Daniel, the Canon and the Grand Narrative of Christianity', in D. Burns \& J.W. Rogerson (eds.), Far From Minimal: Celebrating the Work and Influence of Philip R. Davies, pp. 410-418. T\&T Clark/Continuum, London.

Terrien, S., 1978, The Elusive Presence: Toward a New Biblical Theology, Harper \& Row, San Francisco.
TIME 1989: the Year That Defined Today's World. From Berlin to Beijing, from The Simpsons to the Exxon Valdez, 2009, TIME Books, New York.

Trible, P., 1993, 'Treasures Old and New: Biblical Theology and the Challenge of Feminism', in F. Watson (ed.), The Open Text: New Directions for Biblical Studies? pp. 32-56, SCM, London.

Van der Kooij, A., 1993, "The "critical method" of Abraham Kuenen and the methods of Old Testament research since 1891 up to 1991: Some considerations', in P.B. Dirksen \& A van der Kooij (eds.), Abraha Contribution to the Study of the Old Testament, pp. 49-64, Brill, Leiden.

Van Imschoot, P., 1954, Théologie de l'Ancient Testament, Desclée et Cie, Tournai.

Van Leeuwen, C., 1986, 'Theologie van het Oude Testament', in A.S. van der Woude (red.), Inleiding tot de studie van het Oude Testament, bl. 211-227, Kok, Kampen.

Vermes, G., 1998, Providential Accidents: An Autobiography, SCM, London.

Von Rad, G., 1957, Theologie des Alten Testament, Band 1: Die Theologie der geschichtlichen Überlieferungen Israels, Kaiser, München.

Von Rad, G., 1960, Theologie des Alten Testament, Band 2: Die Theologie der prophetischen Überlieferungen Israels, Kaiser, München.

Vriezen, Th.C., 1974, Hoofdlijnen der Theologie van het Oude Testament, Veenman \& Zonen, Wageningen.

Westermann, C., 1978, Theologie des Alten Testaments in Grundzügen, Vandenhoeck \& Ruprecth, Göttingen.

Wilson, A.N., 2008, Our times: The Age of Elizabeth II, Hutchinson, London.

Wright, G.E., 1952, God Who Acts: Biblical Theology as Recital, SCM, London.

Wyatt, N., 1999, s.v. 'Asherah', in K. Van der Toorn, B. Becking \& P.W. Van der Horst (eds.), Dictionary of Deities and Demons in the Bible, pp. 184-195, Brill, Leiden.

Zenger, E., 2003, 'Der Psalter im Horizont von Tora und Prophetie: Kanongeschichtliche und kanonhermeneutische Perspektiven', in J-M. Auwers \& H.J. de Jonge (eds.), The Biblical Canons, pp. 111-134, Peeters, Louvain.

Zimmerli, W., 1975, Grundriss der alttestamentlichen Theologie, Kohlhammer, Stuttgart. 